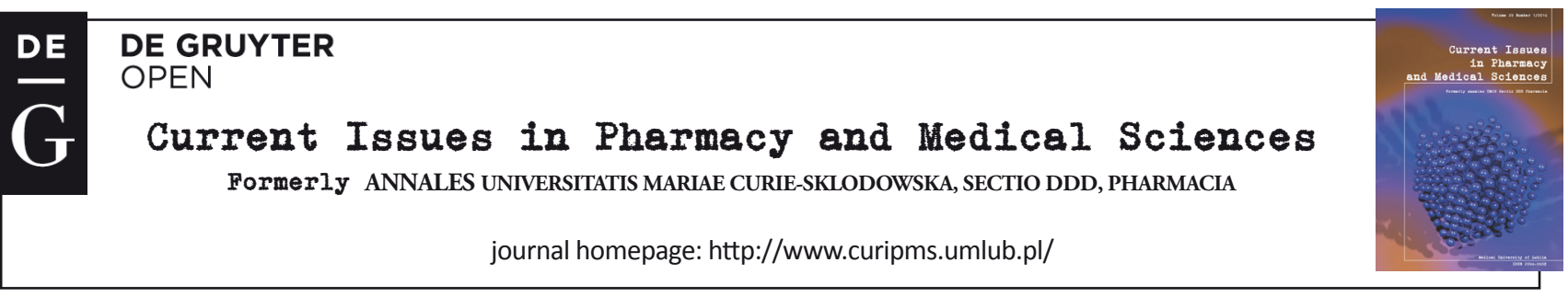

\title{
The survival of dental implants with different implant-abutment connection systems
}

\author{
Piotr SzPaK ${ }^{1}$, Jolanta Szymanska ${ }^{2 *}$ \\ ${ }^{1}$ Individual Dental Practice “Dentistry Implantology Piotr Szpak”, Białystok, Poland \\ ${ }^{2}$ Chair and Department of Paedodontics, Medical University of Lublin, Poland
}

\begin{tabular}{|c|c|}
\hline ARTICLE INFO & ABSTRACT \\
\hline $\begin{array}{l}\text { Received } 21 \text { December } 2016 \\
\text { Accepted } 15 \text { January } 2016\end{array}$ & \multirow{2}{*}{$\begin{array}{l}\text { The aim of the study was to evaluate the survival of implants with different implant- } \\
\text { abutment connection systems, in patients who had two kinds of implants implanted. In } \\
\text { total, } 240 \text { implants were implanted }-91 \text { implants with conical abutment Morse connection, } \\
\text { and } 149 \text { with an internal hexagonal connection. During the follow-up period of } 3 \text { years and } \\
10 \text { months, the percentage of lost implants with a conical implant-abutment connection } \\
\text { was } 1.1 \% \text {. Regarding the implants with hexagonal implant-abutment connection, this } \\
\text { figure was } 0.7 \% \text {. Our work shows that there is a need for further research on the survival } \\
\text { of dental implants. In this, the influence of other factors should be explored that are } \\
\text { related both to the specific implant treatment, as well as to socio-demographic factors. }\end{array}$} \\
\hline $\begin{array}{l}\text { Keywords: } \\
\text { dental implants, } \\
\text { dental abutment, } \\
\text { survival analysis. }\end{array}$ & \\
\hline
\end{tabular}

\section{INTRODUCTION}

Prosthetic treatment using implants, consists of reconstruction - in the most natural way - of dental defects arising as a consequence of caries, periodontal disease, or congenital lack of teeth. The final result of treatment should have, additionally, a beneficial effect on the functioning of the stomatognathic system, together with improved chewing function, speech and aesthetic appearance. Implantoprosthetic treatment is a method that allows for a fully functional and esthetic filling of the missing teeth, and has been shown to satisfy the high expectations of patients. Lack of the implant-bone abutment during the first stage of treatment, and loss of bone-implant integration - in the second stage - lead to the loss of the implant. This is equivalent to the lack of success of the implant treatment $[3,11,15,16]$.

\section{MATERIAL AND METHODS}

The study comprised 28 patients aged 37-66 years (mean age 55.8 years), including 11 men and 17 women, who had at least one of the two kinds of implants seated type I - implants with conical abutment Morse connection (DENTSPLY Friadent ANKYLOS $®$ ) and type II - implants with an internal hexagonal connection (MIS Seven ${ }^{\circledR}$, Alpha-

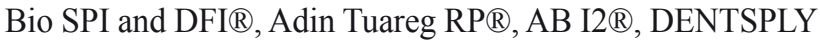
Friadent Xive $\left.{ }^{\circledR}\right)$. In total, 240 implants were implanted

* Corresponding author
e-mail: szymanska.lublin@gmail.com
tel.: +48601 165205

(91 type I and 149 type II implants). The shortest observation time was 4.9 months, the longest - 46 months after the implantation procedure.

\section{AIM}

The aim of the study was to evaluate the survival of implants with different implant-abutment connection systems, in patients who had two types of implants implanted.

\section{RESULTS}

In the course of implant treatment, in the case of two implants, there was no osseointegration, and the dentist decided to remove them during the implantoprosthetic treatment. This was one implant with conical abutment (DENTSPLY Friadent ANKYLOS $®$ ), and this incident represents $1.1 \%$ of the total number of type I implanted implants. The second implant was an internal hexagonal abutment implant (Alpha-Bio DFI $®$ ), and this incident represents $0.7 \%$ of the total number of type II implanted implants.

\section{DISCUSSION}

In our research, through an observation that lasted up to 46 months, $98.9 \%$ of conical abutment implants survived, as did $99.3 \%$ of hexagonal abutment implants. 
The most valuable information relating to the survival of implants is contained in the publications which describe the results of multicenter studies. They show that on the basis of 10 -year follow-up, a survival rate of $96.7 \%$ among 5590 implants of six different connection systems was demonstrated (Brånemark System ${ }^{\circledR}$, Friadent Frialit-2 ${ }^{\circledR}$, IMZ ${ }^{\circledR}$, Ankylos $\AA$, Camlog $\AA$, Komet $($ ). Moreover, the percentage of surviving implants largely depended on the kind of implant and the center where the treatment was carried out [6].

The survival of implants might be related to the type of implant-abutment connection. In the case of a hexagonal abutment for the reconstruction of prosthetic toothless jaws, in 221 patients with 995 implants (four or more implants NobelSpeedy® using the All-on-4 ${ }^{\mathrm{TM}}$ ), some $98.6 \%$ of the implants survived a period of 5 years [8]. Tandlich et al. [17] describe the effect of prosthetic solutions in the form of implant-based prostheses MIS $\AA$, on the survival of implants, in 82 patients. During a follow-up lasting over 30 months, $95.8 \%$ of 265 MIS $\AA$ implants survived. In contrast, Levin et al. [5] evaluated the survival of 1387 implants of type MIS $\AA$, Zimmer Dental ${ }^{\circledR}$, Biomet $3 \mathrm{i}{ }^{\circledR}$ with single prosthetic restorations in the form of crowns, over 6 years. They found that the average survival rate was $93.1 \%$.

Numerous publications concerning the survival of implants with a conical abutment show that such had the greatest relative survival rate, as compared to other types. Morris et al. [10] in their publication, showed that within a 5-year period, from among 1500 implants, $98.3 \%$ of all conical abutment (DENTSPLY Friadent ANKYLOS $®)$ implants survived. What is more, relatively high survival rates (98.2\%) were seen involving 275 DENTSPLY Friadent ANKYLOS $®$ implants loaded prosthetically in the form of a single crown, during an 8-year follow-up period [2]. Beyond the aforementioned, in one of his works, Nentwig [12] rated the survival of 5439 DENTSPLY Friadent ANKYLOS ${ }^{\circledR}$ implants, with an average prosthetic restoration loading time, as equal to 56.8 months. In the case of a single tooth, the survival rate was $98.7 \%$, while the survival rate with a prosthetic supplement restoring missing posterior teeth was $97.9 \%$. Furthermore, in cases, where a high number of missing teeth were reconstructed by implant prosthetics, the survival rate was $97.3 \%$, while for a smaller number of missing teeth, it was $95.8 \%$.

The survival of the implants involves the following factors as well: the experience of the implantology center (multicenter study) [1,6], the dimensions of the implants (length, diameter) [19], the use of single or combined implants in the prosthetic phase [12], the place of implanting $[6,7]$ and the habit of smoking $[8,14]$. At the same time, other publications have not demonstrated the effect of the above-mentioned and other factors on the survival of implants $[4,5,7,9,13,18]$.

Regardless of the above-mentioned factors, there is a need for further research - the analysis of the relationship between the loss of the implant and the socio-demographic characteristics (gender, age) and the factors associated with specificity of implant treatment, such as raising the bottom and reconstruction of the maxillary sinus, the construction of implants, the impact of position of the implants relative to the compact bone, the type of restoration and the time between implantation and loading of the implant with prosthetic restoration.

\section{CONCLUSIONS}

1. The percentage of lost implants with a conical implantabutment connection was $1.1 \%$, while the figure for implants with hexagonal implant-abutment connection was $0.7 \%$ - during the period of a follow-up of 3 years and 10 months.

2. There is a need for further research on the survival of dental implants. This should explore the influence of other factors related both to the specific implant treatment, as well as to socio-demographic factors.

\section{REFERENCES}

1. Chou C.T.S.: AICRG Part II: Crestal bone loss associated with the ANKYLOS implant: loading to 36 months. J. Oral Implantol., 30, 134, 2004.

2. Döring K., Eisenmann E., Stiller M.: Functional and esthetic considerations for single-tooth ANKYLOS ${ }^{\circledast}$ implant-crowns: 8 years of clinical performance. J. Oral Implantol., 30, 198, 2004.

3. Koszuta A., Szymańska J.: The level of patient satisfaction with implant treatment of missing teeth. Curr. Issues Pharm. Med. Sci., 25, 243, 2012.

4. Levin L. et al.: Long-term marginal bone loss around single dental implants affected by current and past smoking habits. Implant Dent., 17, 422, 2008.

5. Levin L., Sadet P., Grossmann Y.: A retrospective evaluation of 1,387 single-tooth implants: a 6-year follow up. J. Periodontol., 77, 2080, 2006.

6. Lin Y. et al.: A clinical retrospective study of 10 years of implant results. Chin. J. Stomatol., 41, 131, 2006.

7. Machtei E.E. et al.: Dental implants for immediate fixed restoration of partially edentulous patients: a 1-year prospective pilot clinical trial in periodontally susceptible patients. J. Periodontol., 78, 1188, 2007.

8. Maló P., Nobre M., Lopes A.: The rehabilitation of completely edentulous maxillae with different degrees of resorption with four or more immediately loaded implants: a 5-year retrospective study and a new classification. Eur. J. Oral Implantol., 4, 227, 2011.

9. Mertens C. et al: Use of 8-mm and 9-mm Implants in Atrophic Alveolar Ridges: 10-Year Results. Int. J. Oral Maxillofac. Implants, 27, 1501, 2012.

10. Morris H.F. et al.: AICRG Part I: A 6-year multicentered, multidisciplinary clinical study of a new and innovative implant design. J. Oral Implantol., 30, 125, 2004.

11. Myśliwiec L. et al.: Leczenie implantoprotetyczne wrodzonego braku drugich siekaczy w szczęce. Implantoprotetyka, 8, 39, 2007.

12. Nentwig G-H.: The ANKYLOS ${ }^{\circledast}$ implant system: concept and clinical application. J. Oral Implantol., 30, 171, 2004.

13. Rasouli Ghahroudi A.A.R. et al.: Radiographic vertical bone loss evaluation around dental implants following one year of functional loading. J. Dent., 7, 89, 2010.

14. Schwartz-Arad D. et al.: Smoking and complications of endosseous dental implants. J. Periodontol., 73, 153, 2002.

15. Stupka M.: Przykłady zastosowania wszczepów dentystycznych w różnych przypadkach braków zębowych. Część pierwsza - etap chirurgiczny. Implantoprotetyka, 30, 17, 2008.

16. Stupka M.: Przykłady zastosowania wszczepów dentystycznych w różnych przypadkach braków zębowych. Część druga - etap protetyczny. Implantoprotetyka, 30, 23, 2008.

17. Tandlich M. et al.: Removable prostheses may enhance marginal bone loss around dental implants: a long-term retrospective analysis. J. Periodontol., 78, 2253, 2007. 
18. Vandeweghe S., Bruyn H.: The effect of smoking on early bone remodelling on surface modified Southern Implants ${ }^{\star}$. Clin. Implant Dent. Relat. Res., 13, 206, 2011.

19. Winkler S., Morris H.F., Ochi S.: Implant survival to 36 months as related to length and diameter. Ann. Periodontol., 5, 22, 2000. 